
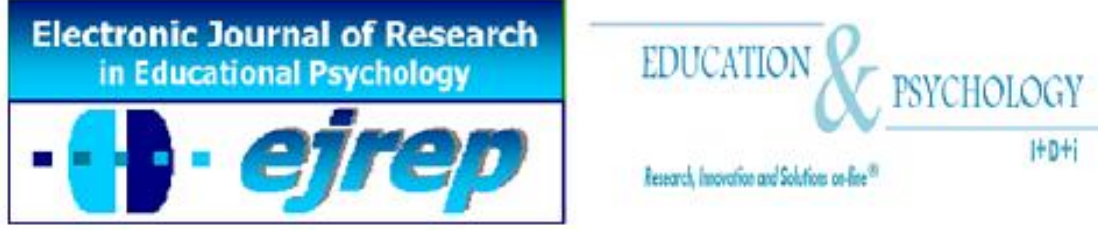

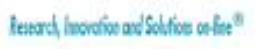

\title{
Lecturer perspectives on dyslexia within one Greek university: A pilot study
}

\section{Aglaia Stampoltzis $^{1}$, Elisavet Tsitsou ${ }^{2}$, Helen Plesti $^{3}$ \& Rani Kalouri ${ }^{4}$}

\author{
${ }^{1,4}$ ASPETE, Department of Pedagogical Studies, Athens \\ ${ }^{2} 8^{\text {th }}$ Primary School of Paleo Faliro, $4^{\text {th }}$ Local Education Authority of Athens, \\ Athens \\ ${ }^{3} 2^{\text {nd }}$ Primary School of Mandra, Local Education Authority of West Attica, \\ Athens
}

\section{Greece}

Correspondence: Aglaia Stampoltzis, 3, Androu street, 15121 Athens, Greece. E-mail: 1stamp@ambio.gr

(C) Education \& Psychology I+D+i and Ilustre Colegio Oficial de la Psicología de Andalucía Oriental (Spain) 


\section{Abstract}

Introduction. Dyslexia is a learning difficulty which affects people in different ways. During the last decades the number of students with dyslexia entering higher education increased steadily.

Method. This paper reports a pilot study exploring the attitudes, views and experiences of faculty members at one small size Greek university regarding students with dyslexia. Data were collected through a three-part questionnaire focusing on academic staff knowledge of dyslexia, approaches towards effective tuition and attitudes towards dyslexic students.

Results. Results indicated that lectures hold mainly positive attitudes and genuine interest for dyslexic students but they also have concerns about 'the fairness' of teaching and other accommodations for students with dyslexia.

Discussion. Following the social model of disability, the paper moves to the direction of making teaching environments as inclusive as possible for students with 'hidden' disabilities. The present study can provide useful ideas about the improvement of provision for students with dyslexia in Greek higher education institutions.

Keywords: dyslexia, specific learning difficulties, students with dyslexia, lecturer perspectives 


\section{Perspectivas docentes sobre la dislexia en una universidad griega: un estudio piloto}

\section{Resumen}

Introducción. La dislexia es una dificultad de aprendizaje que afecta a personas de diferentes maneras. Durante las últimas décadas el número de estudiantes con dislexia que ha ingresado a la educación superior ha aumentado de manera constante.

Método. Este trabajo presenta un estudio piloto explorar las actitudes, opiniones y experiencias de los miembros de la Facultad pequeña de una universidad griega con respecto a los estudiantes con dislexia. Los datos fueron recolectados a través de un cuestionario con tres partes se centra en el conocimiento del personal académico de la dislexia, enfoques hacia la matrícula y las actitudes hacia los estudiantes disléxicos eficaz.

Resultados. Los resultados indicaron que la importancia de mantener actitudes principalmente positivos y genuino interés para los estudiantes disléxicos, pero también tienen preocupaciones acerca de "la equidad" de la enseñanza y otros aspectos organizativos para los estudiantes con dislexia.

Discusión. Siguiendo el modelo social de la discapacidad, los resultados se mueven en la dirección de crear entornos de enseñanza lo más inclusivo posible para los estudiantes con discapacidades "ocultas". El presente estudio puede aportar ideas útiles acerca de la mejora de la prestación para los estudiantes con dislexia en las instituciones de Educación Superior griegas.

Palabras clave: dislexia, dificultades específicas de aprendizaje, los estudiantes con dislexia, perspectivas conferenciante 


\section{Introduction}

Dyslexia has been defined as a lifelong disability that occurs in approximately $10 \%$ of the population, with $4 \%$ showing severe 'symptoms'. Dyslexia primarily affects the acquisition and use of written language, memory and organisational skills. Almost by definition, individuals with dyslexia are likely to have difficulty in coping with many aspects of the formal education system, including reading, spelling and writing Accompanying weaknesses may be identified in the areas of speed of processing, short-term memory, sequencing, auditory and/or visual perception. Dyslexia can occur despite normal cognitive ability and adequate teaching (British Dyslexia Association, 2007; Serrano \& Defior, 2004). A good indication of the severity and persistence of dyslexic difficulties can be gained by examining how the individual responds or has responded to well founded intervention (Rose, 2009, p.10).

Between 1999 and 2010 the number of students with dyslexia entering higher education increased dramatically. In UK, the number of students declaring dyslexia increased from 8,370 to 32,655 representing the $1.3 \%$ of the student population in the UK Higher Education in 2009/2010 (HESA, 2011; Mortimore, 2012). AHEAD (2008) estimates that there are currently more than 10 times as many students with dyslexia in UK universities as there were in 2005. In the US, the most noticeable increase in US universities was reported for students with dyslexia between the years 1988 and 1994 (Thomas, 2000). Furthermore, the proportion of students with dyslexia in first year US universities stood at $2.4 \%$ in the year 2000 and reached 5\% by 2005 (HEATH, 2001). Similar or bigger trends are also reported in other countries (e.g. the prevalence of features consistent with dyslexia is $17.6 \%$ among female Emirati university students who experience difficulties in both English and Arabic).

National Working Party on Dyslexia in Higher Education (1999, p.15) believes that the reason for this increase is due to the following factors: earlier identification and provision for school children with dyslexia, increased support for students with dyslexia within higher education and wider access for 'mature' students (a number of 'mature' students are dyslexics who were not identified at an earlier age and who dropped school or college). 
Although the needs and rights of disabled students as learners in higher education have been officially recognized in many countries (i.e. Australia, UK, United States of America and Israel), it is obvious that achieving positive support for disabled students requires more than legislative change (MacLean \& Gannon, 1997). Higher education institutions are gradually recognizing that disability issues 'cannot remain closed within a student services arena but must become part of the mainstream learning and teaching debate' (Adams \& Brown, 2000, p. 8).

University students with dyslexia face difficulties in a number of key areas such as reading comprehension of large textbooks, organization and writing assignments, spelling, reading speed, working memory, making notes in lectures, organization of time, concentration, passing writing exams, maths/numeracy processing, using the library (Cameron \& Nunkoosing, 2012; Carroll and Iles, 2006; Fuller et al., 2004; Mortimore \& Crozier, 2006; National Working Party on Dyslexia in Higher Education, 1999). Studies investigating experiences of students with dyslexia suggest that dyslexic students face obstacles and misunderstanding in their communication with academic staff in higher education. In addition, dyslexic students drop out at a higher rate than students without dyslexia (Richardson \& Wydell, 2003) or they take them longer to complete their degree programs in comparison to their counterparts (Murray et al., 2000; National Working Party on Dyslexia in Higher Education, 1999).

One factor that could explain the struggle that many students with dyslexia face in higher education is the relationship they have with university faculty. According to Cook, Rumrill and Tankersley (2009), the success of any college student is to some degree determined by the type and the quality of interactions that he or she has with his or her instructors. This is particular important for students with disabilities. Their achievement is influenced by faculty's knowledge of the relevant laws, willingness to provide accommodations, use of effective instructional strategies and knowledge of dyslexia characteristics (Riddell \& Weedon, 2006; Sander, 2005).

Some of the difficulties that dyslexic students encounter at university are: lack of information at the entrance of university, academic staff appeared too busy to help (Holloway, 2001), inconsistency in understanding and provision of dyslexia within and between departments and universities (Riddell \& Weedon, 2006), lack of flexibility in means of assessment methods (i.e emphasis on written assessment), differences between educators' beliefs and 
their actual practices. In addition, many students with dyslexia are fearful of an unsympathetic attitude, feel a stigma attached to being dyslexic and choose not to declare dyslexia from the beginning of their studies or resist incorporating dyslexia into their identity (Jamieson \& Morgan, 2007; Riddick, 2010).

Cook, Rumrill and Tankersley (2009, p. 85) suggest that without a basic understanding of a student's disability, faculty members may believe that students with disabilities are trying to take advantage of or cheat the system. Because dyslexia is a 'hidden' disability, especially in the adult life, staff sometimes may think of dyslexia as a 'middle class ruse' (Kameron \& Nunkoosing, 2012). Moreover, students with dyslexia encounter a wide variety of responses from academic staff, ranging from supportive to unhelpful (Holloway, 2001). Positive staff attitudes are usually informed by personal interest in dyslexia issue, rather than institutional training or policies (National Working Party on Dyslexia in Higher Education, 1999).

\section{Dyslexia in Greek higher education}

Dyslexia is a legally recognised disability in Greece according to the Law 3699/2008. Students with a formal diagnosis of dyslexia can enter higher education after oral examination arrangements. According to Stampoltzis (2003), the percentage of students with dyslexia who entered higher education in a sample of schools in Attica in 2001-2002 was 1.9\%. More recent statistics of the Ministry of Education (2005-2006), suggest that the prevalence of dyslexia in graduates of secondary education differs significantly between different regions of Greece, ranging from $0.3 \%$ in small districts up to $2.4 \%$ and $3.6 \%$ in larger districts around big cities (Athens, Salonica). However, there is no data about how many of the dyslexic students managed to enter higher education in 2005-2006.

Stampoltzis and Polychronopoulou (2008) conducted a study to estimate the incidence of dyslexia among the Greek student population. Data were collected from all Greek public institutions of higher education $(\mathrm{N}=32)$. The incidence of dyslexia was estimated to be $0.16 \%$ which shows that although students with dyslexia form the largest group of students with disabilities, they are significantly under-represented in Greek higher education. Stampoltzis and Polychronopolou (2008) proposed the following reasons to explain this situation: lack of awareness among administrative and academic staff, lack of national guidelines on the assessment and support of dyslexic students, lack of written policy within and between universi- 
ties, lack of special teaching modifications, fear of stigmatization if declaring dyslexia at university. The only official provisions offered to students with dyslexia in higher education are oral exams and generic counseling. In 2011, a new law (4009/2011) reforming higher education was voted by the Greek parliament. As far as dyslexia is concerned the law states that the assessment of dyslexic student must be specified by the internal regulation of each university. Despite the minor changes in legislation on provision for dyslexia, many attitudinal and practical barriers still exist and there is still a long way to go for the Greek higher education institutions.

\section{Rationale of the study}

The needs and rights of students with dyslexia as learners in higher education have been officially documented in many countries but their achievement is influenced by faculty attitudes and their willingness to provide appropriate support. There has been very little investigation into the views and perspectives of university staff about dyslexia. There are still concerns about the fairness of allowing dyslexic students special provision and additional contact with staff and questions about whether people with learning difficulties should be given university places at all (Cameron \& Nunkoosing, 2012; Riddell \& Weedon, 2006). As the views and attitudes of staff are likely to have an impact on student's learning and self-esteem, it was felt that an exploration of staff knowledge and perspectives are justified, particularly as there has been no research at all within the Greek higher educational system.

More specifically, the present study explores the knowledge, beliefs and attitudes of academic staff towards dyslexia. In addition, it examines the teaching methods and accommodations used by staff members for the benefit of dyslexic students. Demographic variables (sex, age, years of working experience, experience with dyslexia and speciality) are also examined in relation to staff views and beliefs.

\section{Method}

\section{Participants}

The research was conducted in a small size Greek university who caters for around 3.000 students. 19 out of 187 members of the academic and teaching staff of the university 
responded to the survey. The response rate was $10.2 \%$ which is low. The respondents seem to represent the part of the academic staff with the more positive perceptions and attitudes to dyslexia and dyslexic students. The demographic characteristics of the sample are presented in Table 1.

Table 1. Demographic characteristics of the sample

\begin{tabular}{ll}
\hline Ages & Participants $(n=19)$ \\
$30-39$ & $7(36.8 \%)$ \\
$40-49$ & $7(36.8)$ \\
$50+$ & 5 \\
\hline Sex & 7 \\
Men & $12(63.2 \%)$ \\
Women & \\
\hline Years of working experience & $10(52.6 \%)$ \\
$6-10$ & 7 \\
$11-20$ & 2 \\
$21-30$ & \\
\hline Experience with dyslexic students & $14(73.7 \%)$ \\
Yes & 5 \\
No & 1 \\
\hline Subject speciality & 3 \\
Engineering & $13(68.4)$ \\
Psychology/Education & 3 \\
Physics/Chemistry & 1 \\
Management & \\
Missing data & \\
\hline
\end{tabular}

\section{Materials}

The data for this study were collected through a questionnaire designed around three main foci of interest: academic staff knowledge of dyslexia, approaches towards effective tuition and perceptions/attitudes towards dyslexic students. Thirteen questions were asked around the first focus and sixteen questions around the third focus. The second focus (effective tuition and accommodations for dyslexic learners) was researched through an open-ended 
question. The question was: 'Please describe any strategies, practices or accommodations you use when you teach students with specific learning difficulties (dyslexia)'. The answers were grouped and presented numerically and verbally in a Table.

\section{Procedure}

During the fall semester of 2013, a list with the e-mail addresses of all full-time and part-time teaching staff was obtained from the Records' Office of the university. Each participant was send via e-mail the survey questionnaire, a cover letter and a campus address return envelope. The letter explained the purpose of the survey and the importance of the input for the development of programs and services for students with dyslexia. Anonymity was assured and the letter indicated that participation was voluntary. The study was also announced by posters in several points within the university. Respondents were allowed three weeks to complete and return the questionnaire. A follow-up reminder e-mail was sent to all staff two months later. At the end of the fall semester, the questionnaires were collected and analysed statistically. The problem of the low survey return rate was taken into account when conclusions are drawn (Churchill \& Iacobucci, 2005).

\section{Statistical Analysis}

Descriptive and non-parametric inferential statistics were used to analyse the data collected.

\section{Results}

\section{Staff knowledge, views and attitudes}

The first result concerns staff knowledge of dyslexia. Table 2 presents descriptive statistics (mean percentage scores and standard deviations) for the first part of the questionnaire revealing staff general knowledge about dyslexia. On average, staff answered correctly $73.68 \%$ of the questions, answered wrongly $15.79 \%$ of the questions, and answered 'don't know' $10.41 \%$ of the questions. This means that the present sample displays moderate to high level of knowledge of dyslexia, concerning the definition, symptomatology and etiology of the condition. The questions which attracted the most misconceptions or lack of knowledge were: the hereditary basis of dyslexia, dyslexia as a phonological deficit, medication and dyslexia and the lifelong nature of dyslexia. 
Table 2. Mean percentage scores (and s.d) in the dyslexia knowledge questionnaire

\begin{tabular}{lrrrrr}
\hline & N & $\begin{array}{c}\text { Mini- } \\
\text { mum }\end{array}$ & $\begin{array}{c}\text { Maxi- } \\
\text { mum }\end{array}$ & Mean (\%) & $\begin{array}{c}\text { Standard } \\
\text { Deviation }\end{array}$ \\
\hline Correct answers & 19 & 53.85 & 92.31 & 73.68 & 13.15 \\
False answers & 19 & .00 & 30.77 & 15.79 & 10.41 \\
'Don't know' answers & 19 & .00 & 30.77 & 10.53 & 9.66 \\
& & & & & \\
\hline
\end{tabular}

No significant differences were observed in staff knowledge of dyslexia regarding sex, age, years of working experience, experience with dyslexic students and subject area (speciality).

Table 3 summarizes participants' answers to the open ended question regarding the instructional or other types of accommodations which academic staff provides for students with dyslexia. Eight helpful strategies are listed based on the participants' preferences, while each participant has mentioned more than one accommodation.

Table 3: Accommodations and teaching strategies for students with dyslexia

\begin{tabular}{l|l}
\hline & $\boldsymbol{n}$ \\
\hline Charts, diagrams, visual materials & 8 \\
Personal attention, counseling, self-esteem reinforcement, & 6 \\
understanding & 5 \\
Technological devices and computer-assisted learning & 5 \\
Key-words, main points of the lecture & 2 \\
Tape recording summary and audio materials & 1 \\
Individual tutoring with extra practice with exercises & 1 \\
Differentiated teaching & 1 \\
Information from dyslexia or other specialists &
\end{tabular}

Staff attitudes and perceptions of the dyslexic students are described below. A majority of the participants $(90 \%)$ agree that being diagnosed with dyslexia does not cause more problems than struggling with dyslexia without identification. In the question if dyslexic stu- 
dents must be obliged to declare dyslexia at university, the views seem to be distributed. More than half of the respondents (58\%) do not agree with the obligatory declaration of dyslexia, while the rest (42\%) agree (Figure 1).

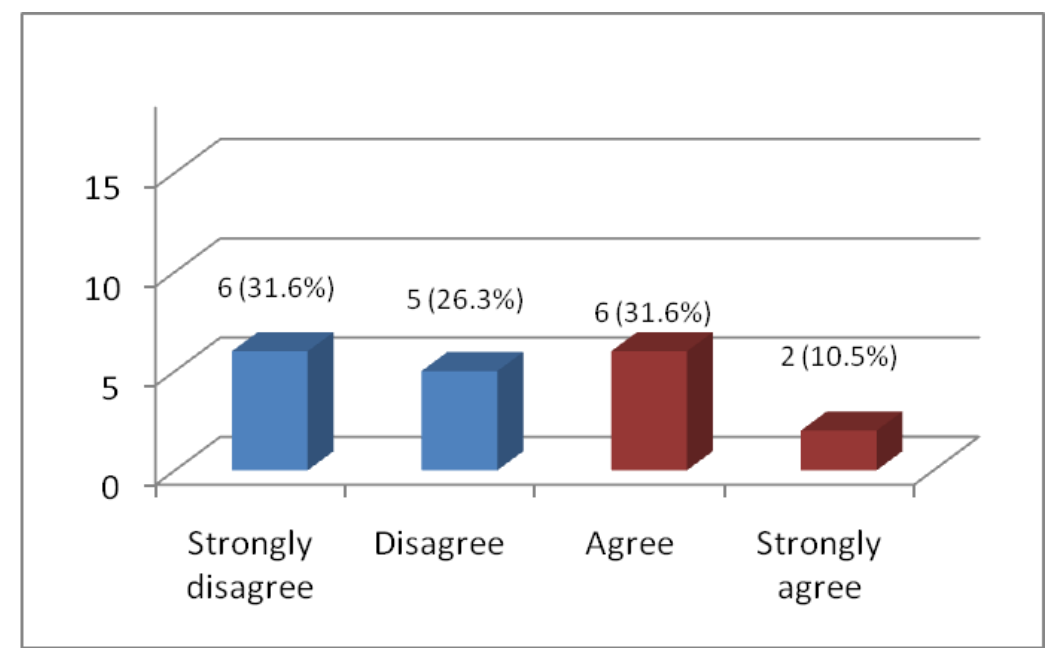

Figure 1. The obligatory nature of the declaration of dyslexia according to the staff

A large majority of the staff $(90 \%)$ believes that students with dyslexia need special examination/testing arrangements. In addition, they think that dyslexic adults are successful in their profession (95\%). Dyslexia is not seen as an excuse which leads to minimal effort, but some of the participants $(26.3 \%)$ believe that the 'label' of dyslexia may be an excuse for some students. Special accommodations in teaching and testing are not seen as 'unfair' for the non-dyslexic population according to a substantial number of staff (79\%). However, in the question whether staff must be free to choose the reasonable adjustments (accommodations), more than the half $(68 \%)$ do not agree. The latter believe that the adjustments must be predetermined.

According to the international trend, students with dyslexia must be eligible to study any course subject. A substantial number of staff members (74\%) agree with this statement but there are tutors who have the opposite view, which means that they believe that some courses must not be offered to students with dyslexia. The academic attainments of students with dyslexia seem not to differ significantly from their peers, according to the $89 \%$ of the participants. Different views are expressed whether the academic staff should change the ob- 
jectives and the content of the curriculum for students with dyslexia. The prevailing perspective of the sample seems to be 'same curriculum for all students' (Figure 2).

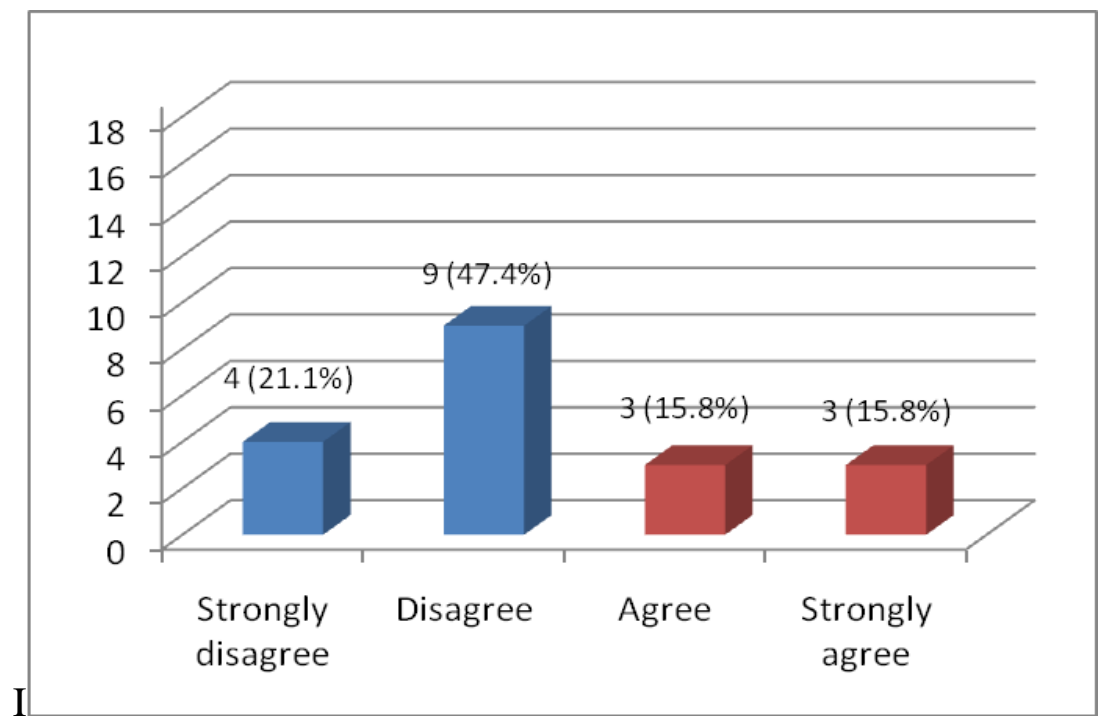

Figure 2. Differentiation of curriculum and course content for the dyslexic students according to the staff

The participants feel able to support dyslexic students (in $89.5 \%$ ), while they believe that the academic staff in general doesn't have enough information and awareness about dyslexia (79\%). Technological tools and computers seem to be essential equipments for dealing with dyslexia according to a majority of the staff (95\%). Staff expectations in general about dyslexic students are not high according to the majority of staff (95\%). However, a substantial number of them (74\%) believe that students with dyslexia make progress in their studies with time.

\section{Demographic variables and faculty responses}

The non-parametric statistical analysis revealed several differences in faculty perceptions and attitudes while the sample of the study is rather small. With reference to age, the Kruskal-Wallis test showed that staff in the younger age group (30-39 years) reported less frequently that dyslexic adults failed professionally in comparison to the older staff (40-49 years and 50-59 years) $\left(\chi^{2}=6.085, d f=2, p<.05\right)$. 
With reference to specialization (engineering/physics/management staff versus education/psychology staff), the Mann-Whitney test showed significant differences in two variables: professional failure in adults with dyslexia $(U=12.5, Z=-2.297, p=0.022)$ and changes in the objectives and contents of the curriculum for students with dyslexia $(U=12, Z=-2.136$, $p<.05)$. Comparing the mean ranks of the two groups, we can conclude that more staff from education/psychology speciality reported professional failure of students with dyslexia compared to staff from other sciences, while staff from social sciences supports the idea for changing objectives and curriculum content for the benefit of dyslexic students.

Years of teaching seem to affect staff perceptions in the following areas: dyslexic students' admission to all courses $\left(\chi^{2}=6.382, d f=2, p=0.041\right)$, academic attainments of dyslexic students $\left(\chi^{2}=87.963, d f=2, p=0.021\right)$, changes in the objectives and the curriculum content $\left(\chi^{2}=6.269, d f=2, p=0.044\right)$ and academic progress through the years $\left(\chi^{2}=7.182, d f=2\right.$, $p=0.028)$. According to the results of the Kruskal-Wallis test, staff with less years of working experience (6-10 years) seems to be more 'flexible' in their approach to students with dyslexia and more optimistic about their academic progress in comparison to the more experienced staff (11-20 years and 21-30 years).

Finally, teaching experience with dyslexia affects what staff believes about the professional competence of students with dyslexia. Staff with more contact with individuals with dyslexia reported greater doubt about the professional success of students with dyslexia ( $U=15, Z=-2,034, p=0.042)$. The latter seems conflicting with the previous results.

\section{Discussion}

The goal of this study was to examine knowledge, attitudes and views of academic staff regarding students with dyslexia. Staff knowledge of dyslexia seemed to be moderate to high although there were misconceptions around topics such as the biological basis of dyslexia, the phonological deficit of dyslexia, the role of medication and the lifelong nature of the condition. We shall mention here that the level of knowledge of staff who were willing to participate in the present study may differ significantly from the level of knowledge of the 'unwilling staff'. However, people in the present study express their need for clear, accessible and comprehensive information about dyslexia. Several studies showed that staff knowledge 
increases after systematic training and contact with dyslexic students (Cameron \& Nunkoosing, 2012; Wadlington \& Wadlington, 2005).

Faculty in the present study were requested to describe accommodations and teaching strategies they use when teaching students with dyslexia. The described adjustments are few, they did not seem to require substantive amount of time, effort or major modification of the nature of the course from the lecturer's side. In other words, lecturers appear to accept little responsibility for supporting students with dyslexia, as it is revealed from their answers in the questions 'changes in the objectives and content of the curriculum' (Disagree $=68.5 \%$ ) and 'freedom to choose reasonable adjustments' (Disagree=68\%). A large majority of them are not willing to make major modifications of the normal teaching procedures, although they are willing to offer exam/testing accommodations (90\%).

Several researchers (Cameron \& Nunkoosing, 2012; Cook, Rumrill \& Tankersley, 2009; Leyser et al., 1998; Mortimore, 2012) suggest that despite the positive attitudes, faculty members are willing to provide accommodations for students with dyslexia and other disabilities only to the extent that they do not lower the academic standards of their courses or demand too much effort or time on the part of the faculty members.

Scott, McGuire, \& Shaw (2001) propose the model of the Universal Design for Instruction (UDI) as an effective approach to teaching because it is characterized by a proactive design and use of inclusive instructional strategies. This model can benefit a wide range of learners (including dyslexic students) and minimize the need for individual accommodation. The guiding principles of UDI are: equitable use, flexibility in use, simple and intuitive use, perceptible information, tolerance for error, size and space for approach, community of learners, and instructional climate (Scott, McGuire, \& Shaw, 2001). According to Cook, Rumrill and Tankersley (2009) it will be helpful to train academic staff in this model to incorporate it in their instruction for the benefit of students with dyslexia.

Another finding of the present research is that although the majority of the participants (90\%) felt that the label of dyslexia is a useful one, it expressed scepticism about the usefulness of the disclosure of dyslexia at university ( $58 \%$ of the staff believes that students should declare their dyslexia on entry, while the rest $42 \%$ disagrees). The issue of disclosure has preoccupied educators and students for years. The first area of contention concerns the tensions 
between confidentiality and effective sharing of information about 'special needs'. Sharing information beyond the teaching staff immediately working with individual dyslexic students or sharing information without explicit permission from the student would be regarded as breaching confidentiality (Matthews, 2009, p. 231). Despite existing procedures encouraging students to disclose their particular learning needs, many choose not to do so because of their previous negative experiences of disclosure, fear of an unsympathetic attitude, staff little understanding of dyslexia or absence of appropriate support (Cameron \& Nunkoosing, 2012; Riddick, Farmer \& Sterling, 1997).

The admission of dyslexic students to all courses attracts some disagreement between staff members in the present study (Disagree=26\%). In UK, before 1999, some universities did not admit students with dyslexia to some courses referred mainly to courses which led to a professional qualification in teaching and courses connected with medicine and/or pharmacy (National Working Party on Dyslexia in Higher Education, 1999). The issue is still controversial (Riddell \& Weedon, 2006). The disability laws in many countries as well as the recommendations of the National Working Party underlie that dyslexia should not be a barrier to entry to any profession, nor a reason for denying any student's admission to a course. There are ways of compensating for the effects of dyslexia such as work closely with members of staff who are responsible for students with dyslexia, consult with the dyslexia tutor, ensure that the student is making use of the support available in the institution, be aware of the special problems may accrue in specific courses, apply the UDI model in teaching etc.

The examination of the relationship between demographic variables and faculty views and attitudes revealed some interesting findings. Gender did not seem to have main effect in our study. Faculty members with less years of working experience (6-10 years) held more positive views about the academic progress and professional success of students with dyslexia, and they support the need for instructional accommodations for dyslexic students. More experienced, older staff who did their academic studies many years ago seemed to be more conservative in their opinions and held reservations about the academic progress and attainments of dyslexic students. On the other hand, staff with more contact with individuals with dyslexia reported greater scepticism about their professional success indicating how difficult is to be dyslexic in a not fully inclusive educational environment. 
Comparisons among different specialities showed that more members of staff from education/psychology faculty took part in the study, reported professional failure of students with dyslexia compared to staff from other sciences and supported the idea for changing objectives and curriculum content for the benefit of dyslexic students. A similar trend is reported by Leyser et al. (1998) who found that faculty in education held positive attitudes toward integration of students with disabilities into college classrooms and were more willing to provide accommodations.

\section{Conclusions}

Generally, the sample of the present study holds mainly positive attitudes towards dyslexic students and they are interested in getting more information of issues related to dyslexia. However, they seem to have contradicting views and practices in some aspects (e.g staff has low expectations for dyslexic students while they believe that students with dyslexia make progress in their studies with time). Policy and practices to promote inclusiveness in Greek higher education are essential. Following the suggestions of the National Working Party on Dyslexia in Higher Education (1999), if more dyslexic students in Greek higher education are given appropriate support, academic tutors and the general public will come to recognize the intelligence, talents and abilities of these students rather than the focusing on the masking effects of dyslexia. There is a major need for training and development activities for faculty as well as a shift from the deficit model of dyslexia to the social model of dyslexia which proposes the change of the teaching environment to be as inclusive as possible (Matthews, 2009).

The social model of disability says that 'even though a person has an impairment that cannot be changed, she or he is still of equal intrinsic worth' (Coleridge cited in Michail, 2011). Higher education institutions and society need to make adjustments in order to include people with dyslexia as equal members of them. Success at college and university is not only a legal and moral imperative, but offers students with dyslexia an opportunity to improve their life, educational level and type of employment (Cook, Rumrill \& Tankersley, 2009).

\section{Limitations}

The results of this study may be considered in the context of a number of limitations. First, the findings are based on data from only one university so their generalizability to other 
universities is limited. Second, the response rate to the survey was low (10.2\%). This means that there may be significant differences in views and attitudes about dyslexia between those who chose to respond and those who did not. The low return rate may have been due to at least three factors. Return rates are typically lower for questionnaires sent by e-mail, e-mail addresses may have change or may be incorrect and e-mails from unknown senders may not be opened and replied for the fear of virus (Cook, Rumrill \& Tankersley, 2009; McKinley, Rogers \& Maclean, 2003). Third, data are obtained solely from self-report questionnaires. In future studies, input from students about faculty behavior should be used to verify data that are based on staff self-reports. Larger studies within and between Greek universities or faculties are needed to fully investigate staff and students' experiences with dyslexia.

\section{References}

Adams, M., \& Brown, P. (2000). Learning, teaching and disability: the need for a new approach. Planet, Special Edition, 3, 7-10. www.gee.ac.uk/planet/senda.pdf (accessed 10 May 2010).

AHEAD (2008). Association on Higher Education and Disability. (2008). Students with disabilities (report) [Online] Available: http://www.ahead.org/

British Dyslexia Association (2007). The Dyslexia Handbook. Reading: British Dyslexia Association.

Cameron, H., \& Nunkoosing, K. (2012). Lecturer perspectives on dyslexia and dyslexic students within one faculty at one university in England. Teaching in Higher Education, 17 (3), 341-352. http://dx.doi.org/10.1080/13562517.2011.641002

Carroll, J.M., \& Iles, J.E. (2006). 'An assessment in anxiety levels in dyslexic students in higher education'. British Journal of Educational Psychology, 76(3), 651-662. DOI: $10.1348 / 000709905 X 66233$.

Churchill, G.A., \& Iacobucci, D. (2005). Marketing research: methodological foundations. California: Sage.

Cook, L., Rumrill, P.D., \& Tankersley, M. (2009). Priorities and understanding of faculty members regarding college students with disabilities. International Journal of Teaching and Learning in Higher Education, 21 (1), 84-96. 
Fuller, M., Healey, M., Bradley, A., \& Hall, T. (2004). Barriers to learning: a systematic study of the experience of disabled students in one university. Studies in Higher Education, 29(3), 303-318. DOI:10.1080/03075070410001682592

Jamieson, C., \& Morgan, H. (2008). Managing dyslexia at university: a resource for students, academic and support staff. London: Routledge.

HEATH Resource Center (2001). 2001 College freshmen with disabilities: A biennial statistical profile. Washington, CD: Author.

Higher Education Statistics Agency (HESA). (2011). Statistics - Students and qualifiers at UK HE institutions. Cheltenham, UK. http://www.hesa.ac.uk/index.php?option_com_content\&task_view\&id_1897\&Itemid_ 239 (accessed July 6, 2011).

Holloway, S. (2001). The experience of higher education from the perspective of disabled students. Disability and Society, 16 (4), 597-615. DOI:10.1080/09687590120059568

Leyser, Y., Vogel, S., Wyland, S., \& Brulle, A. (1998). Faculty attitudes and practices regarding students with disabilities: Two decades after implementation of section 504. A reprint of the Journal on Postsecondary Education and Disability, 13(3), published by the Association on Higher Education and Disability.

McKinley, T., Rogers, R., \& Maclean, R. (2003). Collecting data from physicians via webbased surveys: Recommendations for improving response rates. The Internet Journal of Medical Informatics, 1(1), 11-23.

Maclean, D., \& Gannon, P.M. (1997). The emotionally affected university student: support from the university community. International Journal of Disability, Development and Education, 44(3), 12-26. DOI:10.1080/0156655970440304

Matthews, N. (2009). Teaching the 'invisible' disabled students in the classroom: Disclosure, inclusion and the social model of disability. Teaching in Higher Education, 14 (3), 229-239. DOI: 10.1080/13562510902898809.

Michail, K. (2010). Dyslexia: The experiences of university students with dyslexia. Unpublished Ph.D dissertation. Birmingham: The University of Birmingham.

Mortimore, T. (2012). Dyslexia in higher education: creating a fully inclusive institution. Journal of Research in Special Educational Needs, 13 (1), 38-47. DOI: 10.1111/j.1471-3802.2012.01231.x

Mortimore T., \& Crozier, W.R. (2006). Dyslexia and difficulties with study skills in higher education. Studies in Higher Education, 31 (2), 235-251.

DOI:10.1080/03075070600572173 
Murray, C., Goldstein, D.E, Nourse, S., \& Edgar, E. (2000). The postsecondary school attendance and completion rates of high school graduates with learning disabilities. Learning Disabilities Research and Practice, 15, 119-127.

DOI:10.1207/SLDRP1503_1.

National Working Party on Dyslexia in Higher Education (1999). Dyslexia in higher education: policy, provision and practice (report). Hull: The University of Hull.

Richardson, J.T., \& Wydell, T.N. (2003). The representation and attainment of students with dyslexia in UK higher education. Reading and Writing: An Interdisciplinary Journal, $16,475-503$.

Riddick, B. (2010). Living with dyslexia: the social and emotional consequences of specific learning difficulties/disabilities $\left(2^{\text {nd }} e d\right.$.). London: Roultedge.

Riddick, B., Farmer, M., \& Sterling, C.(1997). Students and dyslexia: Growing up with a specific learning difficulty. London: Whurr.

Riddell, S., \& Weedon, E. (2006). What counts as a reasonable adjustment? Dyslexic students and the concept of fair assessment. International Studies in Sociology of Education, 16 (1), 57-73. DOI:10.1080/19620210600804301

Rose, J. (2009). Identifying and teaching children and young people with dyslexia and literacy difficulties. http://www.interventionsforliteracy.org.uk/assets/Uploads/The-RoseReport-June-2009.pdf (accessed 9 May 2013).

Scott, S. S., McGuire, J. M., \& Shaw, S. F. (2001). Principles of universal design for instruction. Storrs, CT: University of Connecticut, Center on Postsecondary Education and Disability.

Sander, P. (2005). Researching our students for more effective university teaching. Electronic Journal of Research in Educational Psychology, 3 (1), 113-130.

Serrano, F., \& Defior. S. (2004). Dyslexia in Spanish: the state of the matter. Electronic Journal of Research in Educationl Psychology, 2 (2), 13-34.

Stampoltzis, A. (2003). The transition from secondary to tertiary education for pupils with dyslexia in Greece: A pilot study. Epitheorisi Symvouleftikis-Prosanatolismou, 64-65, 109-119 [in greek].

Stampoltzis, A., \& Polychronopoulou, S. (2008). Dyslexia in Greek higher education: A study of incidence, policy and provision. Journal of Research in Special Educational Needs, 8 (1), 37-46. Doi: 10.1111/j.1471-3802.2008.00100.x

Thomas, S. B. (2000). College students and disability laws. http://www.ldonline.org/article/6082/ (accessed 10 June 2014). 
Wadlington, E. M., \& Wadlington, P. (2005). What educators really believe about dyslexia. Reading Improvement, 42 (1), 16-33. 